\title{
Effect of Different Salinity Levels on $\beta$-Carotene Production by Dunaliella sp. Isolates from the Maharlu Lake, Iran
}

Keiwan Ebrahimi Mohammadi (PhD)

Department of Food Sciences, Faculty of Agriculture, Mahabad Branch, Islamic Azad University, Mahabad, Iran

Faraz Arashrad (PhD)

Department of Food Sciences, Faculty of Agriculture, Mahabad Branch, Islamic Azad University, Mahabad, Iran

Corresponding author: Keiwan Ebrahimi Mohammadi

Email: keiwan1976@yahoo.com

Tel: +98-9363679725

Address: Mahabad Branch, Islamic Azad University,

Mahabad, Iran

Received : 20 Feb 2016

Revised: 09 Mar 2016

Accepted: 09 Mar 2016

\section{ABSTRACT}

Background and Objective: Microalgae are a group of algae that produce biochemical products consisting of a wide range of carbohydrates, lipids and proteins that are commercially valuable. Interest in microalgal cultivation is currently blossoming globally. Species of Dunaliella are found in freshwater, euryhaline habitats of all continents, oceans including the Dead Sea and even the salt lakes of the Antarctic. This study investigates the effect of different salinity levels on $\beta$-carotene production by Dunaliella sp.

Methods: Water samples from a hyper-saline lake (the Maharlu Lake in Shiraz) were cultured in modified Johnson media. The $\beta$-carotene content was measured after the samples were treated with different salinities (1,2 and 3M NaCl).

Results: The cell count and $\beta$-carotene content of Dunaliella sp. samples ranged between $0.46 \times 10^{6}$ to $2.12 \times 10^{6}$ cell.mL $\mathrm{L}^{-1}$ and 0.15 to $9.98 \mathrm{pg}^{\text {.cell- }}{ }^{-1}$, respectively. At the end of the experiments, the mean maximum cell content $\left(1.78 \times 10^{6}\right.$ cell. $\left.\mathrm{mL}^{-1}\right)$ and the highest mean $\beta$-carotene content (7.4l pg. cell-1) were obtained at 2 and 3M NaCl concentrations, respectively.

Conclusion: Salinity of the medium might affect the quantity and composition of carotenoids in Dunaliella sp. isolates. Alteration of the culture medium's salinity to $3 \mathrm{M} \mathrm{NaCl}$ significantly increases the accumulation of $\beta$-carotene and total carotenoids in Dunaliella sp. isolates.

Keywords: Dunaliella, Microalgae, Maharlu Lake, $\beta$-carotene. 


\section{INTRODUCTION}

Microalgae are unicellular species, commonly found in marine, freshwater and salt lakes with the size ranging from a few micrometers to a few hundreds of micrometers. This group of algae produces biochemical products consisting of a wide range of carbohydrates, lipids and proteins that are commercially valuable. Dunaliella sp. is a widely distributed halophile green-orange microalgae with an extremely wide range of habitats. Some species such as Dunaliella lateralis live in fresh water, while Dunaliella salina predominates in hypersaline environments (1). When some species of Dunaliella are subjected to environmental stress conditions such as high salinity, high light intensity or nutrient deprivation, they overproduce and accumulate large amounts of $\beta$-carotene (2-6). Studies on the halophilic Dunaliella bardawil have shown a direct relationship between $\beta$-carotene content and salinity [7]. Carotenogenesis is also enhanced under nitrate-limiting conditions (3). In $D$. salina, low nitrate concentrations negatively affect growth, but enhance carotenoid accumulation (8). The Maharlu Lake is located 27 kilometers southeast of Shiraz, Iran, at the latitude and longitude coordinates of $29.4491{ }^{\circ} \mathrm{N}$ and $52.8176^{\circ} \mathrm{E}$ and altitude of about $1460 \mathrm{~m}$. This fishless lake has an estimated average area of $230-280 \mathrm{~km}^{2}$ (depending on evaporation and water influx), maximum depth of 0.5-3 m, and salinity of $119.5-280 \mathrm{gl}^{-1}(2-\sim 4.8 \mathrm{M})(9)$. $\beta$-carotene is a lipid-soluble orange pigment antioxidant, mainly used in cosmetics and food coloring. D. salina is a unicellular green microalga and a rich source of natural $\beta$-carotene (10), which can accumulate $\beta$-carotene to as much as $10 \%$ of the cellular dry weight under certain extreme environmental conditions such as high light intensity, nutrient deprivation, high salinity and extreme temperatures $(3,11-16)$. $\beta$-carotene is the predominant carotenoid in the marketplace, while other carotenoids such as lycopene, astaxanthin, canthaxanthin and lutein have a much smaller market share. While its consumption developed only very moderately, a general rise in prices resulted in an increased overall market value. In 2010, the Baden Aniline and Soda Factory took over Cognis, the only sizable company that produces $\beta$-carotene from algae. In 2011,
Royal DSM N.V. company acquired Vitatene, an important producer of $\beta$-carotene by fermentation. The manufacturing industry structures have been consolidated, which led to disappearance of several companies that were in the market during the mid-2000s. Currently, a limited number of companies dominate this global business. The current market value of commercially used carotenoids is estimated at nearly $\$ 1.2$ billion in 2010 , with a chance to grow to $\$ 1.4$ billion in 2018 with a compound annual growth rate of $2.3 \%$. The market value of $\beta$-carotene, estimated at around $\$ 250$ million in 2007 , increased to just $\$ 261$ million in 2010. This market is expected to grow to $\$ 334$ million by 2018 at a compound annual growth rate of $3.1 \%$. The price of natural $\beta$-carotene ranges from about US $\$ 300$ to $3000 \mathrm{~kg}-1$, depending on the product type and the market demand. In 2010 , the total market value of $\beta$-carotene, both synthetic and natural, was about US $\$ 260$ million, and this is expected to increase to over US $\$ 300$ million by 2018. Most carotenoids are still produced by chemical synthesis, and some studies are being conducted to produce them naturally.

(17).

Ginzburg et al. [18] first reported the presence of Dunaliella sp. in the Maharlu Lake. The purpose of the present work was to study the effect of salinity and light intensity on $\beta$ carotene content produced by Dunaliella sp. isolated from the hyper-saline Maharlu Lake in Iran. Recent temperature rise, increase in water evaporation and decrease in water influx have led to increased salinity. As a result, the population of Artemia sp. (a crustacean) declined, and the abundance of Dunaliella sp. density in the Maharlu Lake in response to high salinity and high temperature has given the lake a red color.

\section{MATERIAL AND METHODS}

\section{Sampling and microalgae isolation}

Three stations/locations were selected from the middle and southern parts of the Maharlu Lake. Wild types of Dunaliella sp. were collected during mid-spring (drought months) and mid-summer in sterile plastic bottles and then transferred to a laboratory. Microscopic examination was carried out to identif Dunaliella sp. Cells based on 
The collected samples were treated with $5 \mathrm{ml}$ (per lit.) of $1 \mathrm{M} \mathrm{KNO}_{3}$ and $0.1 \mathrm{M} \mathrm{KH}_{2} \mathrm{PO}_{4}$, and placed for 7-10 days in a static phytotron (at $25 \pm 2{ }^{\circ} \mathrm{C}$, with $1.5 \mathrm{M} \mathrm{NaCl}$ ). The microalgae was cultivated in modified Johnson's medium with different concentrations of $\mathrm{NaCl}$ (1-3 M) and $\mathrm{pH}$ of 7.5 , adjusted by dilute $(0.01 \mathrm{M})$ and concentrated $(1 \mathrm{M})$ sulfuric acid or sodium hydroxide solutions. In order to avoid precipitation of certain compounds, all stock solutions were sterilized separately (by autoclaving at $121^{\circ} \mathrm{C}$ ) and pooled aseptically. Sodium bicarbonate stock was heat-sterilized at $130^{\circ} \mathrm{C}$. After 10 days, enriched indigenous isolates were cultivated at $25 \pm 2{ }^{\circ} \mathrm{C}$ in $250 \mathrm{ml}$ Erlenmeyer flasks with $100 \mathrm{ml}$ of modified Johnson's medium (ASW) containing $1.5 \mathrm{M}$ $\mathrm{NaCl}$ under a continuous photon flux density of $100 \mu \mathrm{mol} \mathrm{m}-2 \mathrm{~s}-1$. Then, $100 \mathrm{ml}$ of modified Johnson's medium in each flask were inoculated with $50 \mathrm{ml}$ of enriched samples (microalgae). The samples were subcultured several times after microalgae growth to avoid contamination. Colony selection was done according to the following method. First, a well-developed colony was picked up and used as a single clone for further studies. Then, pure culture of the clone was obtained by sub-culturing on nutrient agar. Finally, two-week old colonies were carefully picked and inoculated into 100 $\mathrm{ml}$ of fresh Artificial Sea Water

(ASW) medium in $250 \mathrm{ml}$ flasks. This pure culture was maintained and sub-cultured every fortnight to reach a $\log$ phase as described in the previous studies [10, 19-25].

\section{Non-stress and stress phases}

Isolates were placed in culture media containing $1.5 \mathrm{M} \mathrm{NaCl}$ concentration for 30 days. The most efficient isolate was placed again in the culture medium for 10 days under the same conditions. It was then exposed to different salinities $(1,2$ and $3 \mathrm{M} \mathrm{NaCl})$ for another 20 days. Finally, cell counting and carotenoid measurement (using spectrophotometry) were performed. To compare cell growth in different salinities, cell counting was done using a light microscope and haemocytometer (Neubauer). Each concentration at the desired light intensity was replicated three times. The samples were shaken to homogenize, and $950 \mu 1$ of the sample were transferred to carotenoids accumulation and accumulated $\beta$ carotene concentration per cell basis by screw-cap glass bottle. Then, $50 \mu 1$ of Lugol's Iodine solution were added for fixation. The number of cells was calculated using the following formula: Algae number $($ per $\mathrm{ml})=$ n. 1000 x 0.1. X.

In this formula, $\mathrm{n}$ is the number of Dunaliella sp. cells counted in the large square (total volume of $0.1 \mathrm{~mm}^{3}$ ), while $\mathrm{X}$ was dilution factor applied in combination with the Lugol's Iodine solution (0.95). Cell counting was conducted at the end of 10th day and in a period of 20 days (once every two days). Number of cells was evaluated in $1 \mathrm{M} \mathrm{NaCl}$ [5.8\% (w/v)], $2 \mathrm{M} \mathrm{NaCl}(11.68 \%)$ and $3 \mathrm{M}$ $\mathrm{NaCl}(17.53 \%)$. The samples were cultivated under a photon flux density of $100 \mu \mathrm{mol} \mathrm{m}^{-2} \mathrm{~s}$ ${ }^{1}$ and a $16: 8 \mathrm{~h}$ light-dark cycle, at $25 \pm 2{ }^{\circ} \mathrm{C}$. The $\mathrm{pH}$ value of the culture media was set at 7.5 in static phytotron. Each experiment was repeated three times $[20,25]$.

\section{Pigment extraction and analysis}

Carotenoid production capability of the samples was evaluated according to the protocol provided by Celekli and Donmez [26]. Unlike the first step (ten-day phase), at the stage of stress, the samples were treated with different salinities (1-3 $\mathrm{M} \mathrm{NaCl})$ for twenty days (after the tenth day). In the second phase, the $\beta$-carotene content was measured at $453 \mathrm{~nm}$ by spectrophotometry every two days $[20,25]$.

\section{Statistical analysis}

All data were expressed as means of the three replicated studies. One-way analysis of variance (ANOVA) was used in XLSTAT (ver. 2014.5.03) software, followed by Duncan's test (statistical significance at $99 \%$ confidence interval). Graphs were plotted using the Microsoft Excel (Microsoft Corporation, USA) software.

\section{RESULTS}

Based on morphological examination under light microscope, cell wall-less isolated and purified ovoid algal strains with one cupshaped chloroplast and two equal flagella were identified as Dunaliella sp. In the enrichment step, after adding phosphate and nitrate, growth and reproduction of algae were achieved. Gradual color change of the medium from colorless to a green-orange mixture was noted because of algae growth morphological characteristics. Viability of the cells was determined by a light microscope. 
after about 10 days. Algae grew well after culture in liquid modified Johnson's medium. Spherical shaped colonies appeared 15-30 days after inoculation of algae onto the solidified agar medium. The algae had elliptical (pear-shaped) to rounded shapes.

The samples were investigated in a batch system under different salinity levels. The results were presented as the number of cells per $\mathrm{mL}\left(\times 10^{6}\right.$ cell. $\left.\mathrm{mL}^{-1}\right)$ and accumulated $\beta$ carotene concentration per cell basis (pg.cell ${ }^{-}$ ${ }^{1}$ ) or per $\mathrm{mL}$ of culture broth (mg.mL $\mathrm{m}^{-1}$ ). Table 1 shows the average $\beta$-carotene content and mean number of cells in most efficient isolates from the relevant stations (after 30 days of treatment). According to the preliminary findings, the isolates from station no.3 were considered more productive, because they had the highest amount of $\beta$ carotene per cell. Therefore, the effect of stress conditions in subsequent experiments was evaluated only on these isolates.

The effect of different salinity levels on total Dunaliella sp. during the incubation period is shown in Figures 1-2. The number of Dunaliella sp. cells ranged from 0.46 to $2.12 \times 10^{6}$ cells. $\mathrm{mL}^{-1}$. The total carotenoids content ranged from 0.07 to $11.03 \mathrm{mg}$. $\mathrm{mL}^{-1}$ in the broth culture, and from 0.15 to $9.98 \mathrm{pg}$. cell $^{-1}$ on per cell basis after 30 days at all tested $\mathrm{NaCl}$ concentrations. Results of ANOVA showed a significant correlation between Dunaliella sp. cell density and salinity level $(\mathrm{P}<0.01)$ (Table 2). There were significant differences in the daily measurements of carotenoid contents of Dunaliella sp. grown in defined inorganic medium with 1-3 $\mathrm{M} \mathrm{NaCl}$ concentration after days. The highest mean of maximum total carotenoid content in Dunaliella sp. was recorded at $2 \mathrm{M} \mathrm{NaCl}$ concentration $(7.76$ $\left.\mathrm{mg} \cdot \mathrm{mL}^{-1}\right)$. Carotenoid to cell density ratio $(\beta-$ carotene content per cell) of Dunaliella sp. increased with rising the salinity level. The highest mean of $\beta$-carotene content (7.41 pg.cell ${ }^{-1}$ ) was observed at $3 \mathrm{M} \mathrm{NaCl}$ after 30 days of incubation.

Table 1- Effect of initial $\mathrm{pH}$ value and $\mathrm{NaCl}$ concentration on number of cells and $\beta$-carotene content of Dunaliella sp. after 30 days $\left(\mathrm{pH}=7.5 ; 25 \pm 2{ }^{\circ} \mathrm{C}\right.$ and $100 \mu \mathrm{mol} \mathrm{m}^{-2} \mathrm{~s}^{-1}$ illumination, $\left.1.5 \mathrm{M} \mathrm{NaCl}\right)$.

\begin{tabular}{|c|c|c|c|}
\hline \multirow{2}{*}{$\begin{array}{c}\text { Stations } \\
\text { No. }\end{array}$} & \multicolumn{3}{|c|}{$1.5 \mathrm{M} \mathrm{NaCl}$ and $100 \mu \mathrm{mol} \mathrm{m}^{-2} \mathrm{~s}^{-1}$} \\
\hline & $\begin{array}{l}\text { Number of cells } \\
\left(\text { cell.mL } L^{-1}\right)\end{array}$ & $\begin{array}{c}\text { Total carotenoid } \\
\left(\mathrm{mg.L}^{-1}\right)\end{array}$ & $\begin{array}{l}\text { 及-carotene } \\
\left(\text { pg }^{\text {a }} \cdot \text { cell }^{-1}\right)\end{array}$ \\
\hline 1 & $1.46 \times 10^{6}$ & 6.20 & 3.69 \\
\hline 2 & $1.78 \times 10^{6}$ & 7.76 & 4.27 \\
\hline 3 & $0.98 \times 10^{6}$ & 7.20 & 7.41 \\
\hline
\end{tabular}

a. pictogram

Data are expressed as means of three replicates.

Table 2- Results of ANOVA for number of cells and $\beta$-carotene content per cell of Dunaliella sp. at different salinity levels (1-3 M NaCl).

\begin{tabular}{|c|c|c|c|}
\hline \multirow[t]{2}{*}{ Source } & \multirow[t]{2}{*}{$\mathrm{Df}^{\mathbf{1})}$} & \multicolumn{2}{|c|}{ Mean Squares } \\
\hline & & Number of cells & $\beta$-carotene content \\
\hline Salinity & 2 & $3.13^{* *}$ & $205.59^{* *}$ \\
\hline $\operatorname{Day}(\mathbf{D})$ & 10 & $\mathbf{0 . 3 9} 9^{* *}$ & $56.82^{* *}$ \\
\hline Salinity $\times$ D & 20 & $0.45^{* *}$ & $7.47^{* *}$ \\
\hline Error & 66 & 0.0002 & 0.0061 \\
\hline
\end{tabular}

${ }^{1)}$ Degrees of Freedom

** significant at $1 \%$ probability level 
Figure 1- The effect of different salinity levels on total carotenoids accumulation in Dunaliella sp. during the incubation period ( $\mathrm{T}: 25 \pm 2{ }^{\circ} \mathrm{C} ; 100 \mu \mathrm{mol} \mathrm{m} \mathrm{m}^{-2} \mathrm{~s}^{-1}$ illumination, $1-3 \mathrm{M} \mathrm{NaCl}$ ).

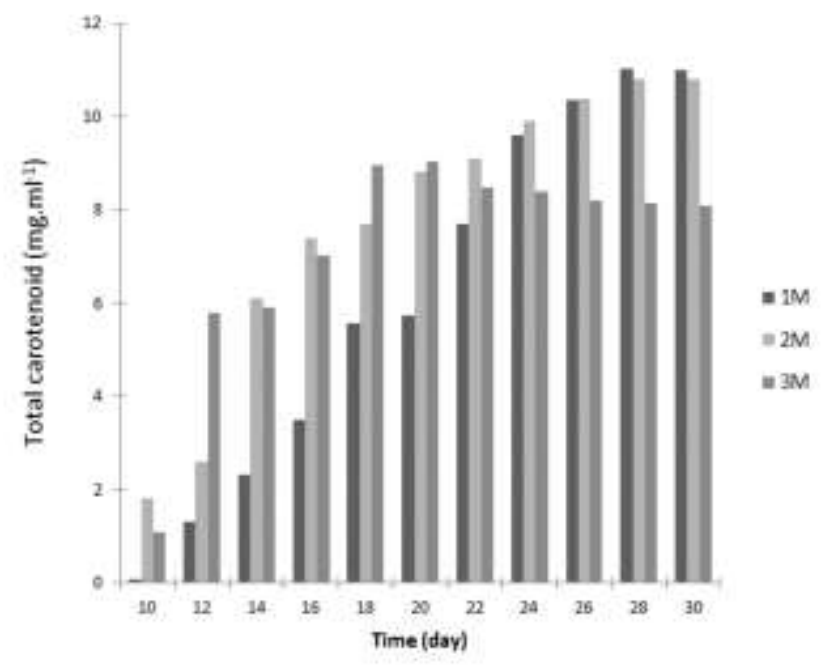

Figure 2- Accumulated $\beta$-carotene concentration on a per cell basis by Dunaliella sp. under different salinity levels during the incubation period ( $\mathrm{T}: 25 \pm 2^{\circ} \mathrm{C} ; 100 \mu \mathrm{mol} \mathrm{m}^{-2} \mathrm{~s}^{-1}$ illumination, $1-3 \mathrm{M} \mathrm{NaCl}$ ).

\section{DISCUSSION}

There were significant differences in the mean total carotenoids content of Dunaliella sp. grown in defined inorganic medium with 1-3 $\mathrm{M} \mathrm{NaCl}$ concentrations. In other words, salinity level affected the cell density and total carotenoid contents.

According to the previous studies, the environmental factors have the biggest impact on carotenoid production by Dunaliella sp. $(10,12,21,26-28)$. The highest $\beta$-carotene content is observed at high salinity, high temperature and high light intensity. Production of carotenoids is usually influenced by the growth rate, as decrease in the growth rate increases the carotenoid production rate $(12,28)$. In the present study, the number of Dunaliella sp. cells increased from 0.46 to $2.12 \times 10^{6} \cdot \mathrm{ml}^{-1}$ under the tested conditions. Moreover, the increase in the culture medium salinity level increased the $\beta$ carotene content (per cell) of Dunaliella sp. from 0.15 to 9.98 pg.cell $^{-1}$ per cell basis after 30 days. However, the productivity on a cellular basis was significantly higher at high salinity concentrations $(3 \mathrm{M} \mathrm{NaCl})$. Consistent with these findings, the studies of Gomez et al. [24] and Fazeli et al. [22] reported that total carotenoid production and cell productivity were affected by salinity level. Maximum biomass production and carotenoid concentrations were compared at different salinity levels. The cell growth rate at $3 \mathrm{M}$ $\mathrm{NaCl}$ was significantly less than that at 1 and $2 \mathrm{M} \mathrm{NaCl}$ concentrations, while the production rate per cell at $3 \mathrm{M} \mathrm{NaCl}$ was significantly higher. These results are in 
accordance with Ben-Amots and Averon (12), Gomez et al. [24] and Fazeli et al. (22). Despite the lower cell density at $3 \mathrm{M} \mathrm{NaCl}$ concentration, the isolate produced more $\beta$ carotene, which could be noteworthy for biotech companies.

\section{CONCLUSION}

Different salinity levels might affect the quantity and composition of carotenoids in Dunaliella sp. isolates. Increasing the culture medium's $\mathrm{NaCl}$ concentration to $3 \mathrm{M}$

\section{REFERENCES}

1. Borowitzka MA, Borowitzka LJ. Dunaliella. Microalgal biotechnology. Cambridge university press. Cambridge, 1988; 27.

2. Ben-Amotz A. New mode of Dunaliella biotechnology: two-phase growth for $\beta$-carotene production. J Appl Phycol. 1995; 7(1): 65-68. doi:10.1007/BF00003552.

3. Ben-Amotz A, Avron M. On the factors which determine massive $\beta$-carotene accumulation in the halotolerant alga Dunaliella bardawil. Plant Physiol. 1983; 72(3): 593-597.

4. Lers A, Biener Y, Zamir A. Photoinduction of Massive beta-Carotene Accumulation by the Alga Dunaliella bardawil: Kinetics and Dependence on Gene Activation. Plant physiol. 1990; 93(2):389-395.

5. Ben-Amotz A, Shaish A, Avron M. Mode of action of the massively accumulated $\beta$-carotene of Dunaliella bardawil in protecting the alga against damage by excess irradiation. Plant Physiol. 1989; 91(3): 10401043.

6. Moradshahi A. Influence of salinity on the growth, pigmentation and ascorbate peroxidase activity of Dunaliella salina isolated from Maharlu salt lake in Shiraz. IJST-Trans. 2004; 28(A1):117-125.

7. Ben-Amotz A, Avron M. The biotechnology of cultivating the halotolerant alga Dunaliella. Trends Biotechnol. 1990; 8:121-126. doi:10.1016/01677799(90)90152-N.

8. Marín N, Morales F, Lodeiros C, Tamigneaux E. Effect of nitrate concentration on growth and pigment synthesis of Dunaliella salina cultivated under low illumination and preadapted to different salinities. $\mathbf{J}$ Appl Phycol. 1998; 10(4): 405-411. doi:10.1023/A:1008017928651

9. Qishlaqi A, Moore F, Forghani G. Impact of untreated wastewater irrigation on soils and crops in Shiraz suburban area, SW Iran. Environ Monitor Assess. 2008; 141(1-3): 257-273.

10. Borowitzka MA, Siva CJ. The taxonomy of the genus Dunaliella (Chlorophyta, Dunaliellales) with emphasis on the marine and halophilic species. J Appl Phycol. 2007; 19:567-590. doi:10.1007/s10811-0079171-x. significantly intensifies $\quad \beta$-carotene accumulation and total carotenoid content in Dunaliella sp. cells.

\section{ACKNOWLEDGEMENTS}

The authors would like to thank the Islamic Azad University of Mahabad for supporting this study.

\section{CONFLICT OF INTEREST}

The authors have no conflicts of interest to declare.

11. Ben-Amotz A. Effect of low temperature on the stereoisomer composition of $\beta$-carotene in the halotolerant alga Dunaliella bardawil (Chlorophyta). J Phycol. 1996; 32(2): 272-275. DOI: 10.1111/j.00223646.1996.00272.x.

12. Ben-Amotz A, Katz A, Avron M. Accumulation of $\beta$-carotene in halotolerant algae: purification and characterization of $\beta$-carotene-rich globules from Dunaliella bardawil (Chlorophyceae) J Phycol. 1982; 18(4): $\quad 529-537 . \quad$ DOI: $\quad 10.1111 /$ j.15298817.1982.tb03219.x.

13. Borowitzka MA, Borowitzka LJ, Kessly D. Effects of salinity increase on carotenoid accumulation in the green alga Dunaliella salina. J Appl Phycol. 1990; 2(2): 111-119.

14. Kleinegris DM, Janssen M, Brandenburg WA, Wijffels RH. The selectivity of milking of Dunaliella salina. Mar Biotechnol (NY). 2010; 12(1): 14-23.

15. Król M, Maxwell DP, Huner NP. Exposure of Dunaliella salina to low temperature mimics the high light-induced accumulation of carotenoids and the carotenoid binding protein (Cbr). Plant Cell Physiol. 1997; 38(2): 213-216

16. Shaish A, Avron M, Pick U, Ben-Amotz A. Are active oxygen species involved in induction of $\beta$ carotene in Dunaliella bardawil? Planta. 1993; 190 363-8. doi:10.1007/BF00196965.

17. BCC Research, Report Code: FOD025C. The Global Market for Carotenoids. Published: [online] March 2008. Available from http://www.bccresearch.com/market-research/food-andbeverage/carotenoids-market-fod025c.html.

18. Ginzburg M, Ginzburg BZ. Ion and glycerol concentrations in 12 isolates of Dunaliella. J Exp Bot. 1985; 36(7): 1064-1074. doi: 10.1093/jxb/36.7.1064.

19. Ben-Amotz A. Glycerol production in the alga Dunaliella. In Biochemical and Photosynthetic Aspects of Energy Production. San Pietro A, editor. New York: Academic Press. 1980; 191-208.

20. Rad FA, Aksoz N, Hejazi MA. Effect of salinity on cell growth and $\beta$-carotene production in Dunaliella $s p$. isolates from Urmia Lake in northwest of Iran. AJB. 2011; 10(12): 2282-2289. 
21. Fazeli MR, Tofighi H, Samadi N, Jamalifar, H, Fazeli, A. Carotenoids accumulation by Dunaliella tertiolecta (Lake Urmia isolate) and Dunaliella salina (CCAP 19/18 \& WT) under stress conditions. Daru. 2006; 14(3):146-50.

22. Fazeli MR, Tofighi H, Samadi N, Jamalifar H. Effects of salinity on beta-carotene production by Dunaliella tertiolecta DCCBC26 isolated from the Urmia Salt Lake, north of Iran. Bioresour Technol. 2006; 97(18): 2453-6.

23. Olmos J, Paniagua J, Contreras R. Molecular identification of Dunaliella sp. utilizing the $18 \mathrm{~S}$ rDNA gene. Lett Appl Microbiol. 2000; 30(1): 80-84.

24. Gomez PI, Barriga A, Cifuentes AS, Gonzalez MA. Effect of salinity on the quantity and quality of carotenoids accumulated by Dunaliella salina (strain CONC-007) and Dunaliella bardawil (strain ATCC 30861) Chlorophyta. Biol Res. 2003; 36(2): 185-92.
25. Hejazi MA, Wijffels RH. Effect of light intensity on beta-carotene production and extraction by Dunaliella salina in two-phase bioreactors. Biomol Eng. 2003; 20(4-6): 171-5.

26. Çelekli A, Dönmez G. Effect of pH, light intensity, salt and nitrogen concentrations on growth and $\beta$ carotene accumulation by a new isolate of Dunaliella $s p$. World J Microbiol Biotechnol. 2006; 22:183-189.

27. Mendoza, H., Jimenez del Rio, M., García Reina, G., \& Ramazanov, Z. (1996). Low-temperature-induced $\beta$-carotene and fatty acid synthesis, and ultrastructural reorganization of the chloroplast in Dunaliella salina (Chlorophyta). EUR J PHYCOL. 2006; 31: 329-331.

28. Borowitzka L, Moulton T, Borowitzka M. The mass culture of Dunaliella salina for fine chemicals: from laboratory to pilot plant. Eleventh International Seaweed Symposium; Springer Netherlands. 1984. 